\title{
THE ISSUES OF FINANCING REGIONAL DEVELOPMENT IN THE REPUBLIC OF SERBIA IN THE EU ACCESSION PROCESS
}

In the accession process of Serbia to the European Union problems of traditional financing of regional development have to be overcome in accordance with international standards and principles. An emphasis should be on reducing disparities, i.e. convergence between regions respecting the approach of the European Union which regards territorial, economic and social cohesion as an efficient instrument for stimulating overall development. A priority is consistently achieving the objectives established in the programs for stimulating balanced regional growth, particularly in the undeveloped regions of the Republic of Serbia. It implies developing systems of direct and indirect incentives to regional growth determined by regulations.

In the accession process the issues of regional development financing have become more complex, as the goals of the regional policy are to be achieved in conditions of enlarged internal and external regional disparities and negative demographic trends. When defining and achieving the main goals of the regional policy and regional development financing systems it is necessary to observe the attitudes of the European Union in terms of reducing convergence, strengthening regional competitiveness, investment activities and employment and interregional cooperation.

Keywords: financing, regional policy, incentive measures, Serbia and the European Union.

Assistant professor, Faculty of Law, John Naisbitt University, Belgrade email: vmiletic68@gmail.com 


\section{Introductory remarks}

Regional disparities in the process of transition and accession to the European Union pose a complex development problem for the Republic of Serbia, due to negative demographic trends and economic disproportions of certain regions. The institutional frameworks of regional development have been improved today due to new regulations in the field of financing, taxation, public-private partnership, commissions, communal services, employment, production incentives, development of enterprise and entrepreneurship in undeveloped regions. The regulations define the aims of stimulating regional development, which are grounded on the European standards and principles. According to the Law on Regional Development new regionalization is established as well as basic directions for regional growth. The Regional Development Strategy for the period between year 2007 and 2012, accepts European orientation in respect of regional policy, thus its aim is to achieve balanced regional development. In that respect there is a tendency towards more efficient exploitation of natural and economic potentials in undeveloped regions, in order to create more favorable conditions for economic growth and investments in those regions. Regional development issues become particularly interesting in the circumstances of unfavorable migration trends and an increase in disparities among developed and undeveloped regions, especially between the core and the periphery.

For defining and meeting priority targets of Serbian regional policy it is necessary to consider the postulates of the EU regional policy for the period between year 2007 and 2012 , whose basic objectives are reducing convergence, strengthening regional competitiveness and employment, and enhancing interregional cooperation. In that context, especially in the accession period, it is important to consider the main principles of financing regional development in the European Union. It should be pointed that new member states are exposed to greater regional disparities, which hinders their integration into the common economic space and represents a challenge for the regional policy in the long run. Thus regional issues have become more complex in the process of transition and the European Union enlargement. In practice, disparities increase, especially between the core and periphery regions in certain countries that have joined the European Union. Problems of regional development financing have become even more complex during the process of Serbian accession to the European Union, because the goals of the regional policy have to be defined and achieved in conditions of distinctive disparities, in accordance with the European standards and principles. Hence it is necessary to develop various sources for regional development in the Republic of Serbia, primarily in terms of budget funds at different levels, pre-accession funds, international support, development credits and other ways of financing. It implies efficient implementation of various incentives to regional and local development, which are determined by 
regulations. It is especially important to the outlined programs for stimulating balanced regional growth in undeveloped and devastated areas of Serbia. The issue of convergence between regions is to be specially regarded, in line with the commitments of the European Union, according to which territorial, economic and social cohesion is treated as an efficient instrument for stimulating overall development. Therefore, Serbian reform of financing regional development should observe international standards and experiences and overcome problems arising from inefficiency of traditional ways of financing.

\section{Regional policy of the European Union}

Due to distinctive disparities at regional level in the European Union there is an institutional liability to work permanently on their long-term reduction. Regional disparities are determined by geographic, historic, economic, politi$\mathrm{cal}$ and other specificities. The issues of convergence among regions are closely regarded in the regional economy of the European Union. The allocation of Cohesion and Structural Funds for developing undeveloped regions supports the prevailing belief that regional disparities will be reduced in the process of economic integration. Territorial and social cohesion is considered to be an incentive to the overall development of the European Union. Distinctive economic and social disparities have been increased with new member states joining the European Union. Thus only three new member states have GDP per capita above $75 \%$ of the EU average (Slovenia, Cyprus and the Czech Republic) while seven states have GDP per capita below $60 \%$ of the EU average (Bulgaria, Romania, Latvia, Lithuania, Poland, Estonia and Slovakia). The given disparities are even more evident at regional NUTS 2 level (70 out of 268 regions have GDP per capita below 75\%, 32 regions below $50 \%$, and 17 regions below $40 \%$ of the EU average). ${ }^{1}$ In these conditions a priority is to fulfill the objectives of the regional policy as a precondition for the EU competitiveness on the global market. In recent times some analyses indicate to a high degree of disparities in regional development. It can be stated that a prevailing attitude in the European Union is towards reducing regional disparities in the long term. Therefore economic, social and territorial cohesion represents a significant objective in the EU Constitution. There are numerous studies and analyses of regional disparities in the European Union in scientific and professional practice that include the relations between developed northern and undeveloped southern regions. Thus, some regions in Greece, Portugal, parts of Spain, and South-East Italy have to 75\% lower GDP per capita than the EU average. ${ }^{2}$ Regional differences have become more distinctive with the EU expansion, since some new member states and many regions have to 50\% lower GDP

European Commission Report on economic and social cohesion, 2007

http://ec.europa.eu/regional_policy

Vol. 13, № 2, 2016: 217-232 
per capita than the EU developed countries. At the same time today there is a tendency to reduce partially international disparities and increase regional disparities within individual states. Some studies have shown that the biggest regional disparities can be found in Great Britain, France and Belgium, while the smallest ones are in Holland, Ireland and Greece (level NUTS2). The coefficient of variation analysis of regional GDP per capita at NUTS 3 level confirms this tendency, while more noticeable regional variations are particularly found in Great Britain, France and Belgium, and the smallest ones are in Sweden, Holland and Spain. ${ }^{3}$ Regional disparities are bigger in the EU developed countries than in the USA. ${ }^{4}$ It has been pointed out that the market and regional policy in the EU often have convergent influence on regional disparities. Relative power of market factors (increase of regional disparities) and the efforts of the regional policy (decrease of regional disparities) affect the level of development of certain regions. Naturally, European labor mobility has an impact on the correlation between the influences of regional disparities and enterprise concentration. Regional disparities are affected by institutional failures on labor market and macroeconomic instability which primarily refers to inflation movements and risks in terms of interest rate. More recently, empirical analyses of institutional influence on regional disparities in the European Union have been highly regarded, while attention is paid to different types of public, communal and private property.

Regional issues become more evident in the process of transition and the EU expansion. At the same time in some countries in transition that have joined the EU disparity between the core and periphery regions has increased (Estonia, Slovakia and Hungary). ${ }^{5}$ Regional analyses point to the fact that disparities are related to specific institutional, geographic and economic factors in some countries, especially in Poland, Romania and Bulgaria. It can be stated that the economic space of new EU member states has a high degree of regional disparity. These states are dominated by an intensive, metropolitan structure, which is confirmed by distinctively higher GDP per capita in the metropolises than the national averages (Hungary, Czech Republic, Poland, Slovakia and other.). Romania and Slovenia have narrow regional dispersion of GDP per capita, while Poland, Hungary, Czech Republic and Slovakia have a wide one. Regional disparities, due to the impact of various factors, have grown in the period of transition and accession of new member states to the EU. A high coefficient of variation at NUTS 3 level is found in Latvia, Hungary, Poland and Estonia, and average variations are found in Czech Republic, Slovakia and Romania. The smallest dis-

Bradley L,Petrakos G..Traistaruc :Integration, Growth and Cohesion in an Enlarged European Union. ZEI, 2006, str. 320

4 Suarez-Villa, L. and J. Cuadrado-Roura:Regional Economic Integration and the Evolution of Disparities, Papers in Regional Science, 1993, 72(4), 369-87.

European Commission: Structural indicators, 2006.

http://ec.europa.eu.int/comm/Eurostat/ 
parities are found in Slovenia and Lithuania. Regional disparities are the same or bigger in these countries in transition than in the EU developed countries (Hungary, Estonia, Latvia and other countries). In these countries disparities between developed and undeveloped regions are uneven, especially in Bulgaria, Hungary and Czech Republic (approx. 1:2.7). New member states are exposed to growing regional disparities, hence a full integration of their regions represents a main challenge for the EU regional policy in the long term.

\section{Financing regional development in the European Union}

The main objectives of the 2007-2013 regional policy are reducing convergence, i.e. disparities among the states and regions (the first objective), strengthening regional competitiveness and employment (the second objective), and improving cross-border, transnational and interregional cooperation (the third objective).

The Structural Funds, i.e. the European Social Fund and the Cohesion Fund are the main instruments for achieving the mentioned objectives of the EU regional policy. The most significant instrument for reaching the objectives of the regional policy is the European Fund for Regional Development, whose resources are allocated to implementing programs for development and information, research, entrepreneurship, information society, infrastructure, energetics, social policy, environment protection etc. The resources of the European Social Fund are allocated to achieving the first two objectives of the regional policy, i.e. financing the programs for boosting business, adaptability of businesses, entrepreneurs and workers, modernization of market and job institutions, education, enhancing administration and fighting discrimination. The resources of the Cohesion Fund are allocated to achieving the first objective of the regional policy, i.e. financing programs in the areas of energetics, transportation infrastructure and environment protection.

In 2006, after having defined the objectives and instruments of the regional policy, the European Commission drew up the list of the member states and regions that had met the criteria for receiving financial support in regional development (statistical regions). By adopting the Regulation the European Council defined the criteria for establishing statistical regions in the member states which represented the basis for their classification. It should be pointed out that the current classification consists of three levels of statistical territorial units (statistical regions). Statistical regions at NUTS 1 level have from 3-7 m population, at NUTS 2 level from $800000-3 \mathrm{~m}$ population and at NUTS 3 level from $150000-800000$ population. ${ }^{6}$ It should be particularly stressed that mere existence of administrative units is not a precondition for obtaining the EU funds. The European Council adopted the Strategic Guidelines for cohesion in

Council Regulation (EZ) no.105/2007

Vol. 13, № 2, 2016: 217-232 
2006, which set a framework for allocation of financial resources from structural funds and for creating national programming documents of the regional policy. Member states were supposed to prepare strategic frameworks and regional operational programs in accordance with this document of the European Council. The main objectives of the EU regional policy are achieved by financing operational programs. Member states are liable to establish a management and control system that is in charge of conducting operational programs and to form a certifying authority, i.e. an authority for monitoring expenses and applications for payments, which are to be submitted to the European Commission. An audit authority is established within this system that is responsible for verifying effective functioning of the management and control system. Efficiency and quality of operational programs implementation are monitored by committees, i.e. the Monitoring Committee in member states.

During the first programming period 2000-2006 after the accession of new member states to the EU there was an urge for defining only one operational program for regional development in certain states. This practice is expected to continue in the future period. Because of the failure to use the allocated resources in the programming periods, the European Commission insists on limiting the amount of the resources for certain states in the new programming period 2014-2020, in which $37 \%^{7}$ of the total resources will be allocated to achieving the regional policy objectives.

In the European Union via the European Commission, the European Investment Bank and the European Bank for Reconstruction and Development conduct common coordinated institutional activities aimed at overcoming regional disparities. Thus, some specific instruments have been created in the preparation of some huge infrastructural projects (JASPERS), the programs for developing small and medium-sized enterprises (JEREMIE) and urban areas (JESSICA).

Within the total EU expenditures for the period 2007-2013 (€975 billion) the frameworks for financing the regional policy ( $€ 347.4$ billion) were defined. Thus $35.7 \%$ of the total EU revenue was directed towards accomplishing the main objectives of the regional development. ${ }^{8}$ The objectives and principles of the regional policy for the period 2007-2013 and the financial resources were defined by the European Council and Parliament by the middle of 2006. At the time, they also determined the criteria for acquiring financial aid as well as the calculation methodology for allocating resources to member states and their regions.

Disparity reduction is achieved by investing in human and physical capital, education, innovation, social protection, administration efficiency and adaptability to social and economic changes ( $€ 282.2$ billion). Hence, $81.5 \%$ of the total resources for the regional policy for this period is allocated for achieving the first goal. The financial resources are provided from the European Fund for Regional

http://ec.europa.eu/regional_policy

8 http://ec.europa.eu/budget/figures/fin 
Development, the European Social Fund and the Cohesion Fund (structural funds). ${ }^{9}$ The resources are aimed at raising the growth rate and development potentials of certain regions.

The regions whose GDP per capita is lower that the EU average obtain $70.51 \%$ of the total amount provided for reducing disparities, i.e. convergence which is the first objective of the regional policy. The regions whose GDP per capita is higher than $75 \%$ of the EU average receive $4.99 \%$ of the budget provided for achieving the first objective of the regional policy. The member states whose GDP per capita is below $90 \%$ of the average obtain $23.22 \%$ of the whole amount provided for achieving the first objective. The member states whose GDP per capita is above $90 \%$ of the average receive $1.29 \%$ of the overall resources provided for reducing economic and social disparities. ${ }^{10}$

In the European Union the funding of $€ 55$ billion from the structural funds is allocated to reinforcing regional competitiveness and employment as the second objective of the regional policy. The regions that are not covered by the first objective of the regional policy (convergence) receive $78.86 \%$, and the other get $21.14 \%$ of this budget. ${ }^{11}$

The financial resources for strengthening cross-border, transnational and interregional cooperation from the European Fund for Regional Development (the third objective of the regional policy) are $€ 8.7$ billion $(2.5 \%$ of the whole budget). Most of these resources is allocated for supporting cross-border cooperation (€6.44 billion), and for transnational cooperation $€ 1.83$ billion and interregional cooperation $€ 455$ million. ${ }^{12}$

\section{The institutional frameworks of regional development in the Republic of Serbia}

The Law on Regional Development, pursuant to the Constitution, includes new regionalization and objectives of balanced development. The Regional Development Strategy of The Republic of Serbia for 2007-2012 confirms European orientation of the regional policy. The emphasis is on a balanced regional development policy, which should stimulate more efficient exploitation of natural and economic potentials in undeveloped regions. In that sense it is necessary to create specific advantages for investments in undeveloped regions. In the Republic of Serbia regional disparities are quite evident, as well as disparities within certain regions, which has an impact on migration flows of the population towards developed industrial centers. There is a trend of increasing dis-

\begin{tabular}{ll}
\hline 9 & Ibid \\
10 & Ibid \\
${ }_{11}$ & Ibid \\
12 & Ibid
\end{tabular}

Vol. 13, № 2, 2016: 217-232 
parities among developed and undeveloped regions. The main problem of undeveloped regions is poorly developed infrastructure, which is a precondition for developing entrepreneurship and investments.

The Law on Regional Development precisely stipulates the objectives of stimulating regional development (overall sustainable development, reducing regional disparities and disparities within regions and negative demographic trends, development of modern economy and competitiveness, new legislative and institutional framework, efficient exploitation of resources at different levels and stimulating regional cooperation). Stimulating regional development is based on the various defined principles (complete regional development, synchronization, solidarity, partnership, subsidiarity, synchronization of the planning systems, the public, efficient control, effectiveness and efficiency of resources, concentration, balanced regional development, respecting the principles and rules of the European Union, rationality and improving the environment). The five regions have been determined for the purpose of stimulating regional development (Vojvodina, Belgrade, Sumadija and West Serbia, South and East Serbia, Kosovo and Metohija). The regions and units of local self-government are categorized according to the level of development on the basis of the established criteria. The developed regions have the level of development above, and the undeveloped regions have the level of development below the average GDP per capita in the Republic of Serbia. According to their development level in relation to the country's average the units of local self-government are divided into four groups. The regional strategies, in accordance with the law, define main priorities of regional development in the Republic of Serbia. The programs for financing regional development contain an overview of projects and distribution of financial resources for their implementation during the fiscal year. The law stipulates the significant subjects of regional development (the Government, the ministries, the provinces, Belgrade, Agencies for Business Registers and Spatial Planning, Development Fund, local self-government units, the Council and Agency for Regional Development, development agencies and councils in regions).

The institutional frameworks of regional and local development were enlarged in 2011 by adopting a number of normative regulations (amendments to the Law on Financing Local Self-Government, income tax, administrative fees, public property, communal services, public-private partnership and commissions, regulations on stimulating production and employment in devastated areas, incentives for development of enterprise and entrepreneurship in undeveloped municipalities, investments in process industries in undeveloped municipalities, development documents, defining the methodology for calculation of development level and criteria for distribution of solidarity transfers among self-government units).

Serbian integration with European structures implies creating conditions for its own development and stability alongside expanding European space of prosperity and democracy. The current stage of Serbian integration with Euro- 
pean economic and political territory is primarily determined by the EU expansion policy, which is an ever-changing process in line with changing conditions. In the Republic of Serbia, in the reform process dominated by evident regional disparities, it is necessary to provide sources for regional development financing in terms of fiscal resources at different levels, pre-accession funds, development loans and international financial support.

\section{Regional policy of the Republic of Serbia}

Regional disparities pose a complex development problem for the Republic of Serbia. The main issues of regional development are economic disproportions and negative demographic trends. Thus the share of Belgrade and South Backa District in the total economic activities of the Republic of Serbia is 30-33\%. ${ }^{13}$ The fact that $36 \%$ of Serbian population live in only 17 towns with more than 50000 inhabitants also indicates to unfavorable demographic tendencies. The reports on Serbian development contain analyses of regional development issues (regional disparities, problems, institutionalization and stimulating regional development). In recent times there is a tendency towards increasing disparities among developed and undeveloped regions, towns and municipalities, urban and rural areas, developed and devastated districts, center and periphery, etc. The correlation between the most developed and the least developed region in the Republic of Serbia in 2011 was 1:2.8. A number of local self-governments have 50-60\% lower income rate per capita than Serbian average. Some devastated districts have 3-4 times lower income rate per capita than the City of Belgrade.

Serbia is undeveloped and relatively lagging behind its near and farther neighborhood. In the previous period, regional development was not a component of Serbian overall social-economic development. Little attention was paid to the fact that economic development has its spatial-regional context. Regional disparities used to be regarded from the aspect of economic disproportions while neglecting their effects on economic development as well as their social and political effects.

Serbian strategic goal is to join the EU, and it is widely accepted both in politics and economy. Serbian integration with European structures implies creating conditions for its own development and stability alongside expanding European space of prosperity and democracy.

The reform of regional development financing in Serbia needs to embrace European experiences, principles and standards, as well as EU regional policy goals, which refer to reducing economic and social disparities in member states and regions, strengthening regional competitiveness and employment and improving cross-border, transnational and interregional cooperation. It is

Report on Serbian regional development, Ministry of Justice, Belgrade, 2012

Vol. 13, № 2, 2016: 217-232 
undisputable that defining regions and principles of regionalization is of the key importance for balanced territorial and economic development of modern states. In the case of Serbia the process of regionalization must be regarded in the context of European integrations.

The regional policy is one of the priorities of the Republic of Serbia in the process of EU integration. It has been confirmed by Serbian National Strategy for EU Accession, which points out to the necessity of embracing European regional policy principles in order to resolve key issues and causes of huge development disparities in the Republic of Serbia. Further to this, an emphasis is on decentralized support of economic and social development of certain regions according to their specific regional issues, then on gradual delegation of administrative competences to regions and municipalities, financing development programs and projects together with local communities, adjustment of the regional policy and strategy to the development strategy of the country. The main goal is to stop further expansion of regional disparities in Serbia in a short-term, and afterwards to reduce those disparities.

Resolving regional issues in Serbia implies defining adequate institutional frameworks where key importance is given to a regionalization unit. In search of the most suitable regional form in Serbia it is necessary to regard the criteria applied in EU member states. In order to create conditions for implementation of the common regional policy the Council of the EU has passed a special regulation $^{14}$, which defines criteria for classification of statistical-territorial units in all EU member states. It is a hierarchical system of classification of the EU territory within national, regional and administrative borders of member states. The current system divides the EU territory, and accordingly member states into three levels (NUTS 1, NUTS 2, NUTS 3). Pursuant to the regulation the Republic of Serbia has set up its statistical regions which will become NUTS regions when Serbia joins the EU. The current administrative division of Serbia into provinces and districts is not in accordance with the EUROSTAT criteria of regionalization at NUTS 1 level, i.e. NUTS 3 level. There is no adequate administrative division in Serbia that corresponds NUTS 2 level. In addition, according to the analysis of own sources and assigned competences districts do not even have any additional attributes of regions which are typical of the EU.

Proposals for Serbian regionalization need to be reexamined from the aspect of homogeneity. Homogeneity criteria can be set up with regard to various indicators while the economic ones should have a priority. Only in that way can we provide consistency of the national regional policy and create conditions for achieving synergetic effects. Unlike the first criterion, the number of population recommended by EUROSTAT, this criterion must be embraced from the aspect of our own national interest, because it provides a long-term basis for numerous

14 EU Regulation 1059/2003of the European Parliament and Council on establishing common classification of territiorial units for statistics (NUTS). 
economic and social policies (fiscal, demographic etc.). Homogeneity imposes the application of cluster analysis of economic, demographic and social structure of certain regionalization variants.

\section{Financing regional development in the Republic of Serbia}

Regional development funds are raised from various sources (budgets at different administrative levels, pre-accession EU funds, international non-returnable financial support, donations and development loans of commercial banks and international financial institutions).

The regulations define the incentives applied in regional development policy (projects implementation, economic and technological development, regional competitiveness, enhancing infrastructure, development capacities and the environment, developing entrepreneurship and under-developed regions).

In the Republic of Serbia there are distinctive differences in the degree of utilization of regional incentives. Thus, $30.4 \%$ of the total resources for stimulating regional development has been allocated to the City of Belgrade, while $9.9 \%$ has been allocated to undeveloped municipalities ${ }^{15}$.

Pursuant to the Law on Financing Local Self-Governments, incentives for regional and local economic development have been increased in the domains of public property, partnership of public and private-owned sector, commissions and communal services. Pursuant to the amendments to the Law on Financing Local Self-Governments $80 \%$ of income tax is allocated according to employees' place of residence and the amount of solidarity transfer is determined according to the development level of local self-governments. A mixed model of financing local self-governments implies more realistic consideration and increasing the primary income of towns and municipalities. In Serbian budget for 2011 transfers to local self-governments were increased by $23.8 \%$ in comparison with the previous year. Out of the total transfer, which was RSD31.8 billion, RSD16.7 billion was allocated to the cities (Belgrade and Novi Sad), and RSD15.1 billion to municipalities (RSD5.6 billion was allocated to distinctively undeveloped municipalities). ${ }^{16}$ In the budget of the Republic of Serbia for 2014 transfers to local self-governments were increased by $4.7 \%$ in comparison with 2011 . The overall transfers allocated to municipalities and cities were 33.3 billion RSD. ${ }^{17}$

The Law on Public Property provides conditions for improving economic efficiency of local self-governments, which is very important given the estimate that the lack of free disposal of property caused municipalities to lose $€ 103$ billion annually. The law defines free disposal and management of property at local

\footnotetext{
$15 \quad$ Ibid

16 Budget Law of the Republic of Serbia for 2011

17 Budget Law of the Republic of Serbia for 2014.
}

Vol. 13, № 2, 2016: 217-232 
level, in order to create more favorable conditions for legal security, economic development and investment activity. This law provides support to public-sector restructuring in the Republic of Serbia. The Law on Public-Private Partnership and Concession Law provide conditions for local self-governments to borrow under more favorable terms from international institutions, and conditions for engaging private capital for the purpose of building infrastructural projects, and attracting resources from European funds.

Direct and indirect incentives to regional development are implemented through numerous institutions of the Republic of Serbia (development fund, competent ministries, agency for insurance and financing export and foreign investments and export promotion, office for sustainable development of underdeveloped regions and European integrations, national employment service and various funds of the state and international aid). In 2011 stimulating financial instruments provided implementation of 1300 projects. $^{18}$

Financial support to economic and regional development of the Republic of Serbia in 2011 was provided through regional state aid ( $€ 231.5$ million), Development Fund (€157.2 million), NIP (€289.1 million), Programs of measures for alleviating negative effects of the economic crisis ( $€ 150$ million), Serbian investment and Export Promotion Agency (€56.8 million), Export Credit and Insurance Agency (€45 million), Agency for Regional Development (€5.1 million) and Office for Sustainable Development of Under-Developed Regions ( $€ 0.43$ million).

The overall financial support of the regional state aid (RSD23.7 billion) accounts for $30.7 \%$ of the total state aid to economic regional development. These funds were collected on the bases of tax incentives (RSD 18.2 billion), loans from Development Fund (RSD 5.1 billion) and subsidies (RSD 398 billion). The regional state aid in 2010 was eight times higher in comparison with the previous year.

The funds of the national investment plan (RSD 29.6 billion), which supported about 200 projects, were mainly allocated to support investments in infrastructure. These funds were increased in comparison with 2010 (€253 million). It should be noticed that the total amount of NIP resources allocated to 2920 projects was approx. RSD 2.2 billion for 2006-2009.

Direct and indirect incentives to economic and regional development are conducted through Development Fund of the Republic of Serbia, which financed 19202 long-term projects in the period 2001-2011 and thus participated with $€ 1.6$ billion. For financing 799 investment projects in 2011 it was stated that $€ 157.2$ million was approved. The Fund's credit support to 147 projects in distinctively undeveloped municipalities accounts for $19.6 \%$ of the total funds. The Fund's resources were allocated to Belgrade District (22\%), South Backa District (6.5\%), Branicevo District (6.3\%), Zlatibor District (6.1\%), Pcinja District (1.7\%) and Jablanica District (2.5\%). The participation of Development Fund of the Republic of

18 See more: Report on development of the Republic of Serbia in 2011, pg. 81-86 
Serbia in GDP for the period 2006-2011 was from 0.52\% (2006) to 1.02\% (2009). It's participation in 2011 was $0.48 \%$.

Programs for stimulating balanced regional development are particularly important for under-developed and devastated regions in the Republic of Serbia. The Office for Sustainable Development of Under-Developed Regions provided 440000 euros for implementation of projects in 2011. Export Credit and Insurance Agency approved 200 credits in 2010. With the purpose of alleviating negative effects of the economic crisis 68.1 billion euros was provided from the budget of the Republic of Serbia in 2011. The funds of the Program for stimulating competitiveness and economic internationalization were 156 million euros. The approved financial support to economy was 156.6 million euros for the period 2006-2011.

International, especially European experiences and standards are to be observed when conducting the reform of regional development financing in the Republic of Serbia. In that respect it is useful to consider possibilities of a modern system of financing regional projects, where regional investment funds emerge as institutional investors, which are formed as the result of partnership between public and private-owned sector. The founders and stakeholders of regional funds are states, foreign investors, banks, insurance companies and pension funds. Thus, in addition to the mentioned basic financing instruments in modern systems, the following instruments appear as important sources for financing regional development such as pre-accession funds, concessions, public-private partnership, public property and efficient collection of city rent. In the accession process to the European Union problems resulting from inefficiency of the traditional way of financing regional development have to be overcome. In that respect a fiscal policy, by mirroring developed countries, must become an efficient instrument of a regional policy. With the purpose of reducing regional disproportions modern systems make use of tax incentives for undeveloped regions, optimal transfers, vertical coordination, horizontal standardization, fiscal decentralization, increasing core earnings, efficient borrowing system, issuing bonds and attracting foreign investments in local self-governments. The fact is that the current stage of Serbian European integrations provides no proper conditions for disposal of pre-accession and other funds aimed at resolving crucial regional issues. 


\section{Conclusion}

In the process of transition and accession to the European Union it is necessary to tackle the problems arising from inefficiency of the traditional way of financing regional development in the Republic of Serbia. In that respect, we have to fully develop a system of direct and indirect incentives to regional development, determined by numerous regulations, in accordance with the standards and principles of the EU regional policy. In the reformation process characterized by distinctive regional disparities it is necessary to develop various sources for financing regional development in the Republic of Serbia, in terms of fiscal resources at different levels, pre-accession funds, development loans and international financial support. It implies continuous monitoring of the regional policy's objectives accomplishment, i.e. the implementation of programs for stimulating regional development, especially in undeveloped and devastated regions of the Republic of Serbia.

The current stage of Serbian European integrations provides no proper conditions for disposal of pre-accession funds aimed at resolving regional issues, while there are also no required institutional frameworks for the implementation of such projects at national level.

In accordance with the EU Council Regulation on defining the criteria for setting up statistical-territorial units in all member states, the Republic of Serbia has established its statistical regions that will become NUTS regions once Serbia joins the EU. In the process of European integrations the regional policy has become a priority of the Republic of Serbia, while an emphasis is on embracing European regional policy principles, i.e. decentralized support of economic and social growth of certain regions in accordance with their specific regional problems, gradual delegation of administrative competences to regions and municipalities, financing regional programs and projects together with local communities, and adjustment of the regional strategy and policy with the country's development strategy.

Complete acceptance of European orientation in the regional policy and the ways of financing balanced regional development has become an imperative of our time. In that respect we have to fully exploit the expanded institutional frameworks of regional development in areas of financing, taxation, public-private partnership, communal services, production and employment incentives, concessions, investments in enterprise and entrepreneurship development in underdeveloped regions. 


\section{Literature}

- Aranđelović, Z.: Strategija regionalnog razvoja, Ekonomski fakultet, Kragujevac,2005.

- Armstrong, Harvey, Taylor:Regional Economics and Policy, Oxford, 2000.

- Borzel, T,:States and regions in the European Union, CambrideUniversity, 2002.

- Bradley, L,Petrakos G.Traistaruc: Integration, Growth and Cohesion in an Enlarged European Union.2006,ZEI, str. 320.

- Budimir, B:RegionalnapolitikaEU 2007-2013,Agenda, br.5., Beograd, 2012,str. 51-55.

- Devetaković, S: Ekonomska regionalizacija Srbije, Ekonomski fakultet, Niš, 2003.

- Evans, A: Eu Regional Policy, Oxford University Press, 2005.

- European Commission : Structural indicators, 2006.

- European Commission Report on economic and social cohesion, 2007

- Budget Law of the Republic of Serbia for 2011

- Budget Law of the Republic of Serbia for 2014.

- Ministry of Economy:Report on development of the Republic of Serbia, Belgrade,2011,pg. 81-86

- Ocić, Č: Uvod u regionomiku, Znamen, Beograd, 2003.

- Rosić, I., Devetaković, S., Jakopin, E: Strategija regionalnog razvoja Srbije, Ekonomski fakultet, Kragujevac, 2004.

- Spirić, D:Finansiranje regiona i regionalnih projekata, Agenda, br. 5., Beograd, 2012.

- Suarez-Villa, L. and J. Cuadrado-Roura: Regional Economic Integration and the Evolution of Disparities, Papers in Regional Science, 1993:, 72(4), 369-87.

- Regulation EZ 1059/2003of the European Parliament and Council on defining common classification of territorial units for statistics(NUTS).

- Council Regulation (EZ) no.105/2007

- Vacić, Z., Mijatović, B., Simić, A., Radović, Z: Regionalizacija Srbije, Centar za liberalno-demokratske studije, Beograd, 2003.

\section{Web pages}

- http://europa.eu.int/comm/Eurostat/

- http://ec.europa.eu/regional_policy

- http://ec.europa.eu/budget/figures/fin 
Doc. DR VESNA MiLeTić

Pravni fakultet, Univerzitet „Džon Nezbit”, Beograd

\section{PROBLEMI FINANSIRANJA REGIONALNOG RAZVOJA U REPUBLICI SRBIJI U PROCESU PRIDRUŽIVANJA EVROPSKOJ UNIJI}

U procesu pridruživanja Evropskoj uniji neophodno je prevazići probleme tradicionalnog načina finansiranja regionalnog razvoja u Republici Srbiji, saglasno međunarodnim standardima i principima. Smanjivanju neravnomernosti, odnosno konvergenciji između regiona treba posvetiti značajnu pažnju, uz uvažavanje stava Evropske unije gde se teritorijalna, ekonomska i socijalna kohezija tretiraju kao efikasno sredstvo za podsticanje ukupnog razvoja. Postalo je prioritetno dosledno ostvarivanje ciljeva utvrdenih $u$ programima za podsticanje ravnomernog regionalnog razvoja, posebno u nerazvijenim regionima Republike Srbije. To podrazumeva razvoj sistema direktnih $i$ indirektnih podsticaja regionalnom razvoju, koji su utvrđeni u zakonskim propisima.

U procesu pridruživanja, izraženi problemi finansiranja regionalnog razvoja postaju složeniji, jer ciljeve regionalne politike treba ostvariti u uslovima povećane spoljne i unutrašnje regionalne neravnomernosti i negativnih demografskih kretanja. U definisanju $i$ realizaciji osnovnih ciljeva regionalne politike i sistema finansiranja regionalnog razvoja, neophodno je uvažavati stavove Evropske unije u odnosu na smanjivanje konvergencije, jačanje regionalne konkurentnosti, investicionih aktivnosti i zapošljavanja i međuregionalne saradnje.

Ključne reči: finansiranje, regionalna politika, podsticajne mere, Srbija i Evropska unija. 